\title{
Home is Where the Heart is: Facebook and the Negotiation of "Old" and "New" During the Transition to College
} Jenna Stephenson-Abetz \& Amanda Holman

This study adopts a dialectical perspective to explore how students transitioning to college communicatively negotiate the web of old and new relationships in the age of Facebook. Interpretive thematic analysis of 30 interviews revealed three discursive struggles: preservation and (re)invention, uniqueness and conformity, and openness and closedness. With time and space no longer inhibiting a connection to all the people in our relational lives, college students must make sense of the possibility for new senses of self when connected to "home" in a way previous generations never experienced. The contradictions present in the participants' voices illuminate the ways in which wider cultural discourses that construct college as a time of separation and independence enable and constrain students' understandings of their own emerging adulthood.

Keywords: College Transition; Emerging Adulthood; Facebook; Relational Dialectics

College is a transitional period of development typified by newfound freedom and independence, exposure to new ideas, new ways of thinking, and diverse student populations. Researchers (McAdams et al., 2006; Schwartz, Côté, \& Arnett, 2005) have shown that identity development, self-exploration, and social experimentation,

Jenna Stephenson-Abetz and Amanda Holman are doctoral students at the University of Nebraska-Lincoln. The authors would like to thank Dawn O. Braithwaite, Editor Bill Eadie, and the two anonymous reviewers for their suggestions and guidance in preparing this manuscript. An earlier version of this paper was a Top Four student paper in the Human Communication and Technology Division at the National Communication Association in New Orleans, LA, November 2011. Correspondence to: Jenna Stephenson-Abetz, University of NebraskaLincoln, Communication Studies, 423 Oldfather Hall, Lincoln, NE 68588, USA. E-mail: jstephenson@huskers. unl.edu 
are all developmentally distinctive aspects of emerging adulthood, especially for students who leave home, go to college, and move closer to becoming adults. These scholars have also asserted that traditionally, college has been a time to leave old communities behind and begin the task of creating an adult identity. However, over the past 7 years, the influence of Internet social networking has radically altered the college experience as the phenomenon of Facebook has dominated as a way for young people to connect and communicate with one another (Peluchette \& Karl, 2010).

The term "emerging adulthood" is the recent phrase parent-child researchers use to describe the age group between the years 18 and 25 (Arnett, 2000; McAdams et al., 2006). Our normative expectations for emerging adults in the United States include a move toward independence and self-sufficiency. This life period is accompanied by an increased concern for privacy, often creating new struggles in relationships with parents. Facebook's role in shaping this transitional period of emerging adulthood represents a unique area of study for communication scholars. Few researchers have sought to understand how students communicatively negotiate the complex web of old and new relationships in the age of Facebook, yet researchers have suggested that computer-mediated communication can support the development of interpersonal relationships (Ellison, Heino, \& Gibbs, 2006). Given that college has traditionally been defined as a time of separation and independence from old communities (McAdams et al., 2006), exploring how students construct and make sense of the possibilities for new senses of self when connected to "home" in such a unique way is an area ripe for communication research.

Boyd and Ellison (2008) traced the history of social network sites back 7 years before Facebook, to the launch of SixDegrees.com in 1997. While this site enticed millions of users, most users did not have wide networks of friends who were online, and service closed in 2000. Early users of the site complained that they were not interested in meeting strangers, foreshadowing that a possible key to a successful social network site would be its functioning as a form of relatedness to those with which one already has some prior offline connection. Since 1997, hundreds of sites such as Friendster, LinkedIn, and MySpace have emerged as a way to connect and relate to others. However, launched in 2004, Facebook has gradually become the leading site for college students. Within 3 years, Facebook was growing at three times the rate of MySpace and had over 7.5 million registered members at more than 2,000 U.S. colleges (Kirkpatrick, 2007). By 2011, Facebook had 750 million members worldwide (Swartz, 2011) and over half of those log on to Facebook daily (Eldon, 2011). In one study, U.S. college students reported using Facebook an average of 10 to 30 minutes daily (Ellison, Steinfield, \& Lampe, 2007). While scholars have explored how much time young adults spend using Facebook and why they use Facebook (Pempek, Yermolayeva, \& Calvert, 2009) we know less about how young adults experience the college transition on Facebook and how it enables and constrains their sense of self. In the current study "old life" represented the individuals' ties and communities they left behind as they moved to college. "New life" signified the transition of establishing new connections within the college community and experience (i.e., new friends, roommates, city, etc.). Our goal in the present study was to understand 
how college students communicate to enact and make sense of self, others, and relationships during this time of change.

\section{College Students' Use of Facebook}

Spending time on social networking sites is part of the daily activities of most U.S. young adults. Some surveys have shown that college students in the U.S. use Facebook for social interaction in their close relationships in order to maintain friendships rather than to make new friends (Ellison et al., 2007), yet others reveal that half of young adult college students used Facebook to make new friends (Lenhart \& Madden, 2007). While the first cohort of students who used Facebook for 4 years of college did not graduate until the spring of 2008, many of today's younger college students have been Facebooking since as early as sixth grade. This makes the generation of today's college students a particularly important sample to examine because they are connected to their past in a way previous generations never experienced. As they move into their dorm rooms and wave goodbye to their parents, many students are simultaneously connected to hundreds of "friends" from home, friends who are communicating their experiences, feelings, excitements, and struggles in the same situations through Facebook.

As online social networking has spread, numerous questions have emerged about its implications for today's college students. Disclosure of information, cyberbullies, and risky behavior are all popular concerns raised in the mainstream media about the use of social networking sites (Koloff, 2008; Stone, 2007). Scholars have examined the link between social networking sites and civic and political involvement (Park, Kee, \& Valenzuela, 2009; Valenzuela, Park, \& Kee, 2009), students' education related use of Facebook (Selwyn, 2009), the characteristics of the typical college user (Raacke \& Bonds-Raacke, 2008) and why students posted information on their profile that would endanger their potential for future employment (Peluchette \& Karl, 2010).

Researchers have also demonstrated how technology is more than something used to quickly coordinate and schedule everyday events. For example, Ling and Yttri (2002) examined how the cell phone functions as a symbol in itself. One of their participants expressed "A mobile telephone is actually an expression of your personality" (p. 1). This sentiment directly applies to social networking communication. Liu (2007) examined how the lists of interests (music, books, movies, etc.) on a social network profile demonstrate one's culturally constrained sense of self. In other words, our interests communicate who we are and what we stand for and these statements are "performed" through the profile. However, our interests and desires do not exist in a vacuum, but are shaped by the people with whom we interact. Thus, in the present study we sought to understand the interactions college students describe as they negotiate the ties to their old and new communities during the transition to college.

\section{Identity as Constituted in Communication}

Identity has traditionally been conceptualized as a psychological phenomenon that is stable and consistent over time (Bergen \& Braithwaite, 2009). In recent literature, 
communication scholars (e.g., Baxter, 2004; Tracy, 2004) have asserted that identities are not internal or fixed aspects of the self. Instead, these scholars posited that identities are constructed through interactions and relationships with others. Identity is created and reproduced in communication, not static but evolving and changing over time and context (Gergen, 1991). Thus, in the present study we sought to highlight the meaning-making of self and relationships as constructions constituted in the process of interaction.

\section{Theoretical Perspective: Relational Dialectics}

We situated the present study within the interpretive paradigm using Relational Dialectics Theory (RDT) (Baxter, 2010; Baxter \& Montgomery, 1996) to highlight tensions and to create a rich understanding of the dialogic meaning-making that emerges from the interaction of competing desires (Baxter \& Braithwaite, 2008). In the present study, a dialectical approach illuminated the contradictory needs and desires that surrounded college students during this time of change. Contradictions, from a dialectical perspective, are an inevitable, natural state of relationships that fluctuate over time (Tracy, 2004). Dialectical tensions are at the core of the meaning-making process and while contradictions always exist in an oppositional relationship, this often entails multiple interrelated oppositions (Erbert \& Alemán, 2008; Fairhurst, Cooren, \& Cahill, 2002). Taking a dialectical perspective allowed us to examine both individual and relational needs and desires and the ways in which they are interconnected.

In addition, grounding the present study in RDT illuminates the transition to college life as an evolving process where young adults negotiate old and new selves and relationships (Baxter \& Braithwaite, 2010). We aimed to advance both the dialogic meaning-making and the contradiction/tension dimensions of relational dialectics. Using the concepts of RDT, each utterance can be viewed as an interdependent thread within a communicative quilt, interwoven to every thread that surrounds it (Baxter, 2010; Baxter \& Montgomery, 1996). In the process of negotiating contradictory desires, the construction of particular social realities takes shape. Dialectical tensions are inherently interdependent as they exist as opposing needs that must be met simultaneously (Putnam, 2004). Thus, in the lives of young adults transitioning to college on Facebook, oppositional forces created situations where students desire both uniqueness and conformity within the various communities that constitute their relational lives, and it is in the interplay, in the negotiation of competing desires, where meaning is created for these students.

We chose RDT because it is especially useful to understanding experiences of change, struggle, challenge, and contradiction (Baxter, 2010). Examining the experiences of college students who are navigating new relationships in college while connected to their past through Facebook is thus an ideal context for a scholar using RDT. In many ways Facebook enables college students to bring "home" into an arena traditionally defined by separation, new beginnings, and newfound independence. Examining how students communicatively negotiated this contradiction and 
perceived of the possibilities for constructing identity in the age of Facebook is a particularly well-suited context in which to use the lens of RDT. Thus, we posed the following research question:

RQ1: What dialectical struggles do students describe as they experience the transition to college on Facebook?

\section{Method}

We situated the present study in the interpretive paradigm using qualitative methods. Baxter and Braithwaite (2008) asserted that interpretive researchers seek "a detailed understanding of how social realities are produced and maintained through the everyday practices of individuals, relational parties, and families" (p. 8). With this in mind, we positioned our study in the interpretive paradigm to highlight the participants' experiences and "native's point of view" of using Facebook in college (Denzin \& Lincoln, 1994).

\section{Participants}

Interpretive researchers' goal is to understand a web of meaning that describes a specific group of people or circumstance (Baxter \& Babbie, 2004). We interviewed 30 male and female students who (a) were at least 19 years of age, (b) enrolled as a freshman or sophomore at a midsized midwestern university, and (c) had an active Facebook account that they check seven or more times per week. In order to recruit participants we used convenience sampling that was approved by the university's Institutional Review Board (IRB).

\section{Data Collection}

Data were collected through semistructured, open-ended interviews with participants. Open-ended questions allowed the participants to provide rich and in-depth descriptions of their experiences using Facebook (Corbin \& Strauss, 2008; Lindlof \& Taylor, 2002; Rubin \& Rubin, 2005). Since we used the lens of RDT, we focused not only on the participants' experiences using Facebook but also treated the interview as a speech event in itself, where we as the interviewers were engaging in the meaningmaking process (Baxter, 2010). Baxter argued that within the process of the interview, the interviewees coconstruct their identity and draw from cultural discourses to render them intelligible to the interviewer.

We developed the interview protocol guided by Rubin and Rubin (2005) and Corbin and Strauss (2008) and created a structured and planned protocol with open-ended questions that elicited in-depth stories about how college students negotiate and manage old and new relationships and identity using Facebook. This protocol helped guide the interview yet allowed enough flexibility to ask additional questions of participants' experiences. Probes were used to maximize the degree of 
depth of each interview. In the end, we conducted 30 interviews which lasted between 15 minutes and 50 minutes with the average length of 32 minutes. From a qualitative perspective, researchers do not stop collecting data when they reach a certain sample size, but, rather, when no new recurring patterns are identified. After 14 interviews, new patterns ceased to emerge in our data, but we continued to interview to ensure that we had a rich sample of experiences from which to draw. Corbin and Strauss noted that at the point of theoretical saturation, all themes are thoroughly developed in terms of "properties, dimensions, and variations" (p. 263). The interviews were recorded and transcribed verbatim following each interview.

\section{Data Analysis}

The purpose of our interpretive analysis was to discover meaning in these data by using RDT and Smith's (1995) guidelines for emerging themes. Smith's guidelines include carefully reading each data transcript, making notes of emerging themes, exploring connections between emerging themes, generating a central list of main emergent themes, and connecting emerging themes with participants' experiences in data set.

We followed Smith's (1995) “idiographic approach” (p. 19) by reading and examining one transcript before moving on to the other transcripts. We then read through all the remaining transcripts at least once to gain a general awareness of participants' perceptions and establish familiarity with the data (Creswell, 2009). To develop the themes, we used Owen's (1984) method of thematic interpretation to meet the three following criteria: (a) recurrence, (b) repetition, and (c) forcefulness.

We used RDT as a sensitizing framework in order to identify dialectical discourses and examine how college students negotiated their "new" and "old" relationships and identities to connect the emerging themes to one another (Smith, 1995). To do this, we collapsed any themes that fell under another theme to produce a "master list of themes" that relates to RDT thematic principles and our research question. For example, we noted that participants experienced a push and pull between staying connected to their old communities and developing an independent self upon entering college, leading us to focus on tensions of "preservation and reinvention" as a central theme. The identification of the dialectical struggles was an interactive and inductive process and at this time in the data analysis any nondialectical themes were dropped from further analysis.

\section{Verification}

Verification is an important element to all research and we verified our results using two different methods. First, we conducted an interactive data conference as is common in our research community (Baxter \& Babbie, 2004; Creswell, 2009). At this data conference we discussed our results with other interpretive and dialectical researchers. They offered constructive feedback of our interpretation of the results 
and we adjusted our analysis according to their feedback. Second, we performed member checks by e-mailing a draft of the manuscript to the participants and requesting feedback and comments regarding the accuracy of our representation of their experiences.

\section{Results}

As we followed our inductive data analysis process, it became clear that a central feature in students' discussions was the negotiation of their old and new relationships and selves as they transitioned to life as a college student on Facebook. Scholars have identified dialectical tensions of old and new in previous studies (e.g., Braithwaite, Baxter, \& Harper, 1998) and use the concept of totality to suggest that we view oppositional desires as interlocking and interdependent. Based on the concept of totality, we identified three primary struggles that relate to the negotiation of old and new selves and relationships: (a) preservation and (re)invention, (b) uniqueness and conformity, and (c) openness and closedness. In what follows, we present and discuss each struggle and the implications these contradictory desires had for college students negotiating old and new selves and relationships.

\section{Preservation and (Re)invention}

Participants described the need for a connection to both their old and new communities. Facebook preserved a connection to the friends, family, and memories they left behind, at the same time that it created a space where the continual reinvention of the self was an ever-present possibility. While students expressed that desiring the preservation of the past and the possibility for reinvention during this transitional phase were not mutually exclusive goals, they were not without tension. This was especially evident in negotiating how to preserve a sense of self that connected to "home" but still left room for independence, growth, and change. A female freshman expressed the desire for connection in this way:

Being away at college, it's a great way to keep connected with your friends back home and keep connected with new friends here... I mean you are always connected with people so it can be hard to be your own person but I really just like to keep connected to all the people I care about. (\#13, 1; note: parenthetical notations refer to the interview number and question numbers from the transcript)

This student enjoyed the opportunity to connect with the people she cared about from both her old and new communities yet also felt it made it difficult to be herself. All of the participants remarked that with Facebook came a constant connection to their old communities. Many students expressed that this connection was an overwhelmingly positive thing because it reminded them of good memories and helped with homesickness during the transition to college. This male freshman described his first semester in this way:

It was a lot easier to move away college because I could still see all the pictures of friends from home. I mean it was lonely in the beginning, so I would just look on 
Facebook at old pictures of hanging out with my high school buddies and the fun times we had ... sometimes I'd just write on their wall and say "hey remember the time....?" (\#17, 11)

This participant believed that Facebook was a positive connection to home because it eased the isolation and homesickness he experienced in the early days of college. With the memories of his old life documented on Facebook, reminders of the people he cared about were only a mouse-click away. For many other participants, Facebook did not simply mean a connection to old friends and memories through pictures or wall posts. Rather, these participants desired the connection Facebook allowed to their old sense of self. This was overwhelmingly expressed in the idea of wanting to preserve the person they were, the person their old friends remembered them to be. A female freshman captured this theme:

When my high school friends look at my Facebook, I want them to see that I'm still the fun, outgoing girl they remember and that college didn't change me. I mean I want them to see me as more mature, but still being the same person they remember. $(\# 14,6)$

While this participant wanted to be seen as more mature, she desired the connection to the old self that made her feel comfortable and happy. While participants craved a connection to their past, they simultaneously wanted to connect to the new world of college through Facebook. This female freshman described:

I got onto Facebook after rush and I had about 400 new friend requests because it was all the new pledges and all the other girls I met. It really helped me, I don't know what I'd do without Facebook. Communicating with those girls on Facebook and then being able to see them around campus, it was like an instant community and I just knew I was going to be okay here. $(\# 11,9)$

For this participant, the ability to connect with so many new people so quickly, increased her sense of belonging and the extent to which she felt comfortable in this new environment. Even though many of our participants felt strongly connected to their old communities because of Facebook, college existed as a fresh start, a new chapter, and a chance to forget about what used to hold them back. In this way, Facebook was the medium through which the reinvention of self was communicated to those watching from "home." This female sophomore exemplified this perception:

My Facebook is an extension of who I am ... I can show new things I'm into. I used to care a lot about what people thought but now I'm more comfortable in my own skin and I can show that on Facebook by the kinds of things I post, it's like you can be a new you, just by your Facebook. $(\# 14,3)$

For this participant, Facebook was an opportunity to present a new self to others, and it was an expression of growth and change aimed to show increasing self-confidence and new sense of self. However, the struggle for participants surrounded what reinvention meant for their desire for connection. In the process of reinvention, two identity-related struggles are played out: reaching out for a new emergent identity while holding safely onto the security of the old identity and old connections. From a developmental attachment perspective, Facebook represents a kind of 'safe haven' 
where students can return to the comfort of old senses of community. The comfort of old connections accessed through Facebook also acts as a 'secure base', allowing students to explore various possibilities for what and whom they want to be (Ainsworth, Blehar, Waters, \& Wall, 1978). However, the desire for reinvention of self upon entering college is also a desire for disconnection. Facebook poses its own challenges to (re)invention and participants voiced the ways in which this is negotiated. A female sophomore explained:

I was studious and quiet in high school and coming to college I just wanted to leave that behind. I'm in ROTC and I joined a sorority and I dyed my hair and just started having more fun. I know my friends from high school comment on some of my pictures and think I've changed and that's fine, I mean I still want to be friends with them but I went out of state because I wanted the independence that came with moving a thousand miles away. Sometimes it feels like I'm still back home. $(\# 11,3)$

This participant believed college was a chance to leave her past in the past and use college as a time to break out of old routines and embrace new opportunities. However, her desire for reinventing herself and disconnecting from her old community was made difficult by the connection to Facebook. The constraints posed by a continual renewal of the past are most evident in participants' struggle for a new self while desiring a connection to home. All participants communicated with friends from high school and most participants were Facebook friends with their parents and members of their extended family. The following account, provided by a female sophomore from a small town, expands on this struggle:

I feel like everyone in my hometown still knows everything about me just from my Facebook, which is kind of creepy. It definitely kind of erases the line of moving to college, because they can just look at my profile and see "oh she's in this club and friends with so-and-so, look who she's friends with" "oh look she's in a relationship now." I think it's a win-lose situation, for example, I like being friends with my mom on Facebook, but if my mom sees something on my FB she's not very fond of she'll call me and ask "why is this on your FB? Take it off!" and that was just not the way college used to be. $(\# 14,12)$

This participant's reflection hints to the potential Facebook carries for altering the previous divide between family life and college life. Students overwhelmingly remarked that Facebook helped them connect to the new world of college at the same time it linked them to the communities they left behind. With time and space no longer inhibiting a connection to all the people in our relational lives, college students must negotiate their conflicting desires for preservation of the pastconnection to the comfort of old and familiar ties-with their desire to disconnect and reach out for new possibilities of (re)invention.

\section{Uniqueness and Conformity}

In transitioning to the new environment of college, participants often described that with the ability to list interests and post pictures, Facebook enabled a strategic and 
selective presentation of self. Further, the asynchronous nature of their interactions (Ellison et al., 2006) gave them more time to consciously construct messages, posts, statuses, and responses to others' comments. While the mediated nature of Facebook gave participants' myriad opportunities to present themselves purposefully and positively, the struggle for participants' surrounded their desires for both uniqueness and conformity within the varying norms and expectations of their old and new communities.

Our participants expressed the belief that their communication on Facebook showcased their uniqueness. For them, choosing which interests, pictures, and statuses they displayed represented an opportunity to communicate the varying aspects of their personalities and priorities. A male sophomore expressed his feelings this way:

I choose to pick a profile picture that shows the things I care about. Right now it's a picture of me and my sisters. They're still in high school and I really take pride in them. I want people to know that I try to keep my family first. $(\# 15,4)$

This participant felt his Facebook profile picture represented a chance to communicate his pride in his family. While all participants expressed that their Facebook communication represented their uniqueness, they simultaneously described a desire to fit in and conform to the expectations of those watching them. A 19-year-old male participant remarked, "With Facebook you're always thinking of how what you say and what you post is going to be perceived" (\#15). Another 19-year-old male participant stated, "If someone comments on my wall, I just think that any one of my 503 friends can see it." (\#9, 14). The need for conformity was often expressed as the desire to communicate a certain image on Facebook. The hard part for participants was not in figuring out what image would gain approval by their old or new relationships, but in how to have their Facebook communication conform to various and often contradictory expectations and still speak to their own uniqueness. A male sophomore captured this struggle:

My close friends from high school are big into their frats but that's just really not for me and I don't party very much. I have felt some distance from them, that maybe I don't fit in with them anymore, so I try to show on my FB that I still have fun even without being in a frat or drinking every night. Well, my parents were always pretty strict and I'm an only child and they only have me to focus on. Last semester during one of our phone calls they said "you look like you're having fun in your Facebook pictures, but remember why you are in college-to learn." And I just wanted to say "what do you want from me? I'm just trying to be me!" (\#27, 7)

Several participants mentioned that part of fitting in with old and new friends meant sharing their relationship status on Facebook. While some participants wanted to be in relationships, they struggled with the idea of disclosing it to all their Facebook friends. A female sophomore described the pressure in this way:

Relationships status. I am about to do it, but I just need a little time. I mean I was in high school and I had a couple of boyfriends and now I have learned a lot from that and I did not really want to be in a relationship and now that I am I want to be 
in one, it just takes a little bit to actually put it out there for the world to see. People are going to say "What?" "Where did that come from?" I am going to have to explain it, which is not a bad thing. It is just kind of a new step. $(\# 1,14)$

While participants described that posting a relationship status was a common way to conform to the expectations of both old and new friends, other participants expressed that the differences in their old and new groups of friends made it hard to negotiate fitting in with both. A male sophomore stated:

I grew up in a big city and knew lots of different kinds of people. Also, politically, I'm very liberal. Well, my new friends here are mainly from small towns and farms and are just a lot more conservative. Last semester one of my friends posted something making fun of Obama and I wanted to comment, but I didn't want to alienate all my new friends in the beginning. And then a few weeks later, one of my friends from high school wrote on my wall to catch up and joked about going cow-tipping when he comes to visit and I wanted to comment, but I knew it'd be like insulting my new friends for being country. My new friends saw the post and asked me if that's what my high school friends think we actually do for fun here. It can be hard to figure out how to maintain friendships with both groups of friends. $(\# 22,14)$

This participant felt torn between old and new friendship loyalties. In the first situation, he wanted to express his political beliefs, but feared distancing himself from newly forming friendships. Second, he desired a connection to his old friend but aligning with his "cow-tipping" wall post meant reinforcing an urban/rural divide that would position his new friends as unenlightened and inferior. Overall, participants believed that Facebook was an avenue to express their uniqueness, but the notion of Facebook as a forum for the expression of individuality often belied more nuanced desires of conformity to all the communities that comprised their social world.

\section{Openness and Closedness}

In the present analysis, negotiating old and new selves was interwoven with tensions about revealing and concealing information on Facebook as well as revealing and concealing knowledge gained from Facebook in face-to-face interaction. One of the main ways that tensions over revealing and concealing manifested in the experiences of our participants was through a navigation of what should be public or private information for their old and new communities. The struggle for them was not simply about whether to be open or not. Rather, they had to negotiate what their revealing and concealing communicated to multiple audiences: friends from the past, many of whom were simultaneously communicating their college experiences from afar on Facebook; parents and extended family, who were eager to see the new activities, accomplishments, and choices of their child/grandchild/niece/nephew/cousin during this transitional phase; and the new community of college friends constituting their present social world. A male freshman captured this theme:

I want my friends from high school to think I'm cool and that my college life is fun, but what does a picture of me partying with friends say to my parents or my 
grandma? I care about what my family thinks too, it's hard to make everyone happy. It's like my old and new friends and my family are smashed together. (\#26,4)

Other students similarly voiced that revealing and concealing was a negotiation of old and new. This female sophomore explained:

My freshman year I got really involved with slam poetry with other girls in my dorm. I'd always post quotes and lines from our poems on my page. Well when I went home for Christmas after my first semester, I found out that some of my old friends were talking behind my back about how I'd gotten weird and I was some sort of poetry freak. I just feel pulled because I still care about some of those friends, but at the same time, this is a new passion of my mind that I love sharing with my new friends and putting on my FB page. $(\# 19,5)$

For this student, revealing college interests on Facebook, meant embracing the new self at the expense of opinions of old friends. When transitioning to college, participants were eager and excited to make new friends and often described how Facebook helped facilitate this process. However, students voiced that a challenge of these newly forming friendships was balancing revealing and concealing knowledge gained from Facebook in face-to-face interaction. This was a challenge because they believed information shared on Facebook often served to eliminate "surface" conversation in person. A female freshman explained:

I was working on a project with a girl from my English class that I wanted to be friends with. When we got together, I already knew some of the music she liked so I just played it from my laptop before she came over and she was like "oh they're my favorite band." I wanted to tell her I already knew that, but I thought it would be weird so I just said "me too" even though that felt a little dishonest. $(\# 17,6)$

For this participant, interests posted by others on Facebook represented an opportunity to establish commonality with a potential friend. The tension lay in the fact that this was a newly forming friendship and revealing that she played the music because she saw that her friend liked it on Facebook was risky and jeopardized a chance for real friendship, while concealing how she knew this information felt dishonest. Other participants echoed this belief and asserted that with access to the postings of friends, both old and new, came the negotiation of openness. One male freshman expanded on this idea:

I always see what people are doing and then it's easy to just pick up where you left off. "Oh Sara went to China" and then when I see her I ask her about her trip. I don't have to have surface conversations because of Facebook. It's kind of weird because you have to balance what to say though. I mean I might see that a guy in my class went to visit his grandma over the weekend but I don't really know him so I might just pretend and say "what'd you do this weekend?" even though I know. You have to balance between being interested and being a creeper. $(\# 17,4)$

For this participant, it was necessary to negotiate how open to be with friends and how much you know about their lives. Overwhelmingly, participants perceived that Facebook made meeting and connecting with new people easier. Additionally, participants appreciated the ability to look at the profiles of new friends and potential 
dating interests because it gave them insight into that person and helped them prepare and generate conversation topics when they later attempted to talk face-to-face. However, the openness they desired of Facebook is the very thing that subsequently made it difficult to conceal information about their relationships. A male sophomore expressed this challenge:

I had people friend me... just because they were friends with my girlfriend and I think they just wanted to check me out and see what I was like. I think they wanted to see our posts to each other and pictures of the kind of things we did together, it's kind of weird. I mean it's really none of their business, but it's not like I'm trying to hide anything, it's just some things should just be private. (\#10, 7)

This participant wanted the ability to communicate openly and share information about his relationship on Facebook, yet he felt that the things he shared should not be revealed to everyone. Other participants described wanting to be open about their new relationships, but worried about what their old friends would think. A male sophomore expressed:

When I went away to school, I knew I didn't want to hide the fact that I was gay anymore. I met some great friends here and I was open with them about it, but when I started dating my first boyfriend, I didn't want it to be official on Facebook. He said "are you embarrassed of me?" and I told him no, I just wasn't ready for my high school friends to know yet. I understand why he would feel this way because it's the normal thing everyone does when they're in a relationship-they're open about it on Facebook, but my old friends are important to me and I'm just still trying to figure it all out. $(\# 23,7)$

This student wanted to be open about his sexuality yet was cautious about revealing his relationship because he was nervous about the judgment of old friends. In this way, the tensions of openness-closedness and uniqueness-conformity are intertwined. Students not only had to negotiate how open or private to be about their own lives when communicating on Facebook, but they had to negotiate the openness of others especially in terms of how much to admit to knowing about their lives. Students' desire to reveal was interwoven with their desire to foster connections to new college communities and to publicly embrace new aspects of themselves. However, in the process of revealing new interests, choices, and relationships they had to negotiate how revealing/concealing would be perceived by old and new communities.

\section{Discussion}

In the present study, we adopted a dialectical perspective to better understand how college students constructed their identities and communicatively negotiated old and new relationships with Facebook. Although we have described several different tensions expressed by our participants, some more of a struggle than others, the experiences of nearly every participant embodied a mixture of these tensions in their lives as college students on Facebook. Overwhelmingly, students loved the ease with which they could connect and communicate with new people on Facebook. Facebooking their college roommate in the months before moving away to get a sense 
of what he or she was like, being "friended" by hundreds of other students in their campus organizations and clubs, and using Facebook to chat casually with classmates, all contributed to their sense of community in the early days of college. At the same time, students asserted that the ability to see pictures of the memories they had made with friends from home and talk to friends who were also going through the transition of moving away from home, lessened their sense of homesickness and fostered a sense of connectedness amid the distance. For all of our participants, there existed an ongoing influence of both their old and new relationships. Indeed, they all communicated (often daily) with friends from high school and members of their family through Facebook while also meeting and connecting with new friends on their college campus. As we discovered, this communication had various and often complex implications for their relationships and their individual and relational identities.

We see this study as a contribution to the literature on relational dialectics and the transition to college. With social network sites existing as a popular venue for relational development, understanding how identities are constructed through interactions and relationships with others (Bergen \& Braithwaite, 2009) is critical to comprehending the process of communicating on Facebook. In what follows, we seek to highlight the way RDT illuminates students' use of Facebook and their negotiation of "old" and "new" relationships and selves.

First, meanings are generated from the struggle of various, often contradictory, discourses (Baxter \& Braithwaite, 2010; Putnam, 2004; Tracy, 2004). The systems of meaning that make the participants' statements intelligible are embedded in wider cultural expectations that define what is appropriate, and what is possible. When students interact on Facebook, many of these distal discourses come into play at once. For example, when students communicate about experiences with family, they often draw on discourses of individualism and independence to explain their feelings while simultaneously intertwining discourses of connection, such as the importance of "remembering where you came from." Students' awareness of how their college experiences shape, and are shaped by, their Facebook communication coupled with a desire to find their place within a narrative that asserts "this is not how college used to be" leads them to attempt to construct their experience of college as "normal." Thus while they may internally feel pulled and conflicted, their negotiation of tensions is very much an interpersonal experience. Indeed, they need to make sense of their own college experience in light of the stories they grew up hearing from their parents, older siblings, and media which construct college as a time of separation. Participants' voices also show the fluid and evolving nature of meaning-making. Once living all aspects of life on Facebook gradually becomes the new "normal," cultural understandings of separation, independence, and connection during the transition to college will evolve as well. And from a constitutive lens, the way we culturally communicate about this time of change will affect the way students organize their reality, the tensions they feel, and the meanings they construct.

Second, while we know that consciousness and identity are constructed through interaction (Baxter, 2010; Bergen \& Braithwaite, 2009), dialectical understandings of Facebook illuminate how young adults experience this transitional time while 
connected and interacting with old and new communities. As the boundaries that separate self from others become increasingly challenged, the past and present interpenetrate in one space to create an awareness of the way our communication is continually shaped by the different expectations of relational others. In this way, Facebook is not a window into students' inner, fixed selves, but a puzzle where the anticipation of responses from varying "others" connects with culturally constrained understandings and students' own contextual desires, constructing and communicating a meaningful picture. Perhaps our new media relationships have fully "saturated" ourselves (Gergen, 1991) leading us to a more complicated fragmentation of the self, as we are constantly and often contradictorily defined by a saturation of interactions. There is a paradox, however, that seems to characterize this social saturation: while we are constantly being redefined in terms of our relationships with others through new media, creating a "self" on Facebook reinforces notions of individualism and autonomy-we have our own pages, select our own "unique" interests, advertisers present messages to us based on our own personal preferences. Thus, "at the very time within which our selves could be opened up to constant redefinition by an "other," we are constituted in reference to an increased positive valence on individualism as we use these media devices" (J. Ewalt, personal communication, July 6, 2011).

Finally, this study highlights that while dialectical tensions may appear to exist as binary oppositions, tensions should be conceptualized as multiple, overlapping, and interdependent (Alemán, 2001; Baxter, 2010). Students wanted connection to old and new relationships and this meant navigating how to belong in a new environment while also navigating the ways in which "home" would always be a part of their sense of self. Desires for connection to "new" are simultaneously desires for disconnection from "old"; desires for uniqueness are tied to the need for reinvention and the pull of conforming to old and new expectations; desires to reveal and conceal are interwoven with desires for connection, reinvention, and preservation. Orenstein (2009) questions how today's generation of college students can become someone new when they remain continually tied to their past. In other words, how do students grow when they exist simultaneously as the old captain of their high school basketball team, an active member of their college sorority, and the responsible daughter making good choices away at college? We would argue that while the multiple interactions that college students experience on Facebook are constantly creating, questioning, affirming, and reinforcing, their present sense of self, identities in everyday life are constantly emerging from communication with others. So while it could be argued that Facebook continually renews old sensibilities of time and place and creates a situation where students never really leave home, we believe that this is not in fact the case. What Facebook allows is more avenues for communication with diverse groups of people in our relational lives. While students form relationships, make mistakes, negotiate life decisions, and communicate the social experience of college along with the old and new relationships in their lives, they simultaneously watch and respond to others as they navigate what and whom they want to be. 
While we have focused on the college transition specifically, we believe that the dialectical struggles college students experience may offer several heuristics for understanding how Facebook is changing the way we think about communication, from any perspective. This may be particularly evident in our shifting notions of what is, or should be, public and private communication, and the way we meet and maintain relationships. From a broader perspective, Facebook may be changing the way we communicate social support to others; shaping our sense of agency in influencing political and social change, including the way we organize to bring about that change; and cultivating a sense of how communication connects us, both locally and globally, to others. We all have different aspects of our identities that we share with different people in our lives. Facebook brings those people together and creates a space where the different parts of our identities collide in both positive and negative ways in front of the different communities we are a part of. The flexible, fluid, and evolving nature of selves and relationships is especially apparent in the experiences of our participants because they are navigating new individual and relational challenges as they leave home, enter college, and begin to develop and explore new goals, interests, and possibilities (Arnett, 2000).

We are left with the question of whether the negotiation we examined might be unique to college students. After all, life at any stage is a series of negotiations of competing desires and, as we move through life, "the cast of relevant characters is ever expanding" (Gergen, 1991, p. 62). Throughout all of our lives, we leave certain communities and become a part of new ones, carrying with us the experiences that constitute our social world. Our findings from the present study may enlighten the role that technology plays in maintaining old connections and identities while establishing new ones. What is unique for the college-aged population is that this may be the first time they have to intertwine and negotiate the different parts of their past and present lives. For many participants, this was the first time they had moved out of the communities in which they were raised, and their Facebook communication shaped the way they experienced this transition. Because of Facebook, students embody the distal discourse that "home is where the heart is" in a way that we believe will continue to alter traditional notions of the college experience, ties to our old communities, and the possibilities of reinventing ourselves. In this way, students' communication on Facebook is a key meaning-making activity in their college life. We construct ourselves and others in interaction, our individual meanings are negotiated within a social context (Gergen, 1991) and, for students, identity is undeniably influenced by the degree of connection Facebook allows to both old and new communities.

\section{Limitations and Future Directions}

While the present study offers communicative contributions to the ways in which college students negotiate old and new selves in the age of Facebook, limitations must be noted. One limitation of the study is that it only considers the young adults' perspective on how they negotiate and manage their old and new relationships. It would 
be helpful to interview members of students' old and new social networks to gain multiple viewpoints of how the college transition is experienced with Facebook. While this study contributes to an understanding of how Facebook shapes early college life, a longitudinal study that captures how young adults continue to manage and negotiate their relational experiences on Facebook throughout their college years would be beneficial. Facebook has clearly influenced the way young adults negotiate themselves as they transition from old communities into new ones, yet understanding the experiences of other age groups would provide a more detailed picture. For example, future researchers could investigate older adults' perspectives of what Facebook means to their sense of self and their understandings of connection and communication with others.

\section{References}

Ainsworth, M. D., Blehar, M. C., Waters, E., \& Wall, S. (1978). Patterns of attachment: A psychological study of the strange situation. Hillsdale, NJ: Erlbaum.

Alemán, M. W. (2001). Complaining among the elderly: Examining multiple dialectical oppositions to independence in a retirement community. Western Journal of Communication, 65, 89-112. doi: $10.1080 / 10570310109374693$

Arnett, J. J. (2000). The psychology of emerging adulthood: What is known and what remains to be known? In J. J. Arnett \& J. L. Tanner (Eds.), Emerging adults in America: Coming of age in the 21st century (pp. 303-330). Washington, DC: American Psychological Association.

Baxter, L. A. (2004). Dialogues of relating. In R. A. Anderson, L. A. Baxter \& K. N. Cissna (Eds.), Dialogue theorizing difference in communication studies (10th ed., pp. 107-124). Thousand Oaks, CA: Sage.

Baxter, L. A. (2010). Voicing relationships: A dialogic perspective. Thousand Oaks, CA: Sage.

Baxter, L. A., \& Babbie, E. (2004). The basics of communication research. Belmont, CA: Wadsworth.

Baxter, L. A., \& Braithwaite, D. O. (Eds.). (2008). Engaging theories in interpersonal communication: Multiple perspectives. Thousand Oaks, CA: Sage.

Baxter, L. A., \& Braithwaite, D. O. (2010). Relational dialectics theory, applied. In S. W. Smith \& S. R. Wilson (Eds.), New directions in interpersonal communication (10th ed., pp. 48-66). Thousand Oaks, CA: Sage.

Baxter, L. A., \& Montgomery, B. M. (1996). Relating: Dialogues and dialectics. New York, NY: Guilford Press.

Bergen, K. M., \& Braithwaite, D. O. (2009). Identity as constituted in communication. In W. F. Eadie (Ed.), 21st Century Communication (10th ed., pp. 165-173). Thousand Oaks, CA: Sage.

Boyd, D. M., \& Ellison, N. B. (2008). Social network sites: Definition, history, and scholarship. Journal of Computer-Mediated Communication, 13, 210-230. doi: 10.1386/macp.4.2.241_3

Braithwaite, D. O., Baxter, L. A., \& Harper, A. M. (1998). The role of rituals in the management of the dialectical tension of "old" and "new" in blended families. Communication Studies, 49, 101-120. doi: 10.1080/10510979809368523

Corbin, J., \& Strauss, A. (2008). Basics of qualitative research: Techniques and procedures for developing grounded theory (3rd ed.). Los Angeles, CA: Sage.

Creswell, J. W. (2009). Research design: Qualitative, quantitative, and mixed methods approaches (3rd ed.). Thousand Oaks, CA: Sage.

Denzin, N. K., \& Lincoln, Y. S. (Eds.). (1994). Handbook of qualitative research. Newbury Park, CA: Sage.

Eldon, E. (2011, June 13). Inside Facebook: Tracking Facebook and the Facebook platform for developers and marketers. Retrieved from http://www.insidefacebook.com/2011/06/13/available-datashows-facebook-user-numbers-growing-quickly-or-slowly-or-falling/ 


\section{J. Stephenson-Abetz and A. Holman}

Ellison, N., Heino, R., \& Gibbs, J. (2006). Managing impressions online: Self-presentation processes in the online dating environment. Journal of Computer-Mediated Communication, 11, 415441. doi: $10.1111 /$ j. 1083-6101.2006. 00020

Ellison, N. B., Steinfield, C., \& Lampe, C. (2007). The benefits of Facebook 'friends:" Social capital and college students' use of online social network sites. Journal of Computer-Mediated Communication, 12, 1143-1168. doi: 10.1111/j.1083-6101.2007.00367.x

Erbert, L. A., \& Alemán, M. W. (2008). Taking the grand out of grandparent: Dialectical tensions in grandparent perceptions of surrogate parenting. Journal of Social and Personal Relationships, 25, 671-695. doi: 10.1177/0265407508093785

Fairhurst, G. T., Cooren, F., Cahill, D. J. (2002). Discursiveness, contradiction, and unintended consequences in successive downsizings. Management Communication Quarterly, 15, 501540. doi: $10.1177 / 0893318902154001$

Gergen, K. J. (1991). The saturated self: Dilemmas of identity in contemporary life. New York, NY: Basic Books.

Kirkpatrick, D. (2007, June 11). Facebook's plan to hook up the world. Fortune. Retrieved from http://money.cnn.com/2007/05/24/technology/facebook.fortune/

Koloff, A. (2008, February 7). States push for cyberbully controls; but efforts to go beyond schools raise concerns over freedom of speech, privacy. USA Today. Retrieved from http://www. usatoday.com/printedition/news/20080207/a_cyberbullying07.art.htm

Lenhart, A., \& Madden, M. (2007). Teens, privacy and online social networks: How teens manage their online identities and personal information in the age of MySpace. Washington, DC: Pew Internet \& American Life Project.

Lindlof, T. R., \& Taylor, B. C. (2002). Qualitative communication research methods (2nd ed.). Thousand Oaks, CA: Sage.

Ling, R., \& Yttri, B. (2002). Hyper-coordination via mobile phones in Norway. In J. Katz \& M. Aakhus (Eds.), Perpetual contact: Mobile communication, private talk, public performance. Cambridge, UK: Cambridge University Press.

Liu, H. (2007). Social network profiles as taste performances. Journal of Computer-Mediated Communication, 13, 252-275. doi: 10.1111/j.1083-6101.2007.00395.x

McAdams, D. P., Bauer, J. J., Sakaeda, A. R., Anyidoho, N. A. Machado, M. A., Magrino-Faillo, K., et al. (2006). Continuity and change in the life story: Longitudinal study of autobiographical memories in emerging adulthood. Journal of Personality, 74, 1371-1400. doi: 10.1111/j.1466494.2006.00412.x

Orenstein, P. (10 March, 2009). Growing up on Facebook. New York Times. Retrieved from http:// www.nytimes.com/2009/03/15/magazine/15wwln-lede-t.html

Owen, W. F. (1984). Interpretive themes in relational communication. Quarterly Journal of Speech, 70, 274-287. doi: 10.1080/00335638409383697

Park, N., Kee, K. F., \& Valenzuela, S. (2009). Being immersed in social networking environment: Facebook groups, uses and gratifications, and social outcomes. CyberPsychology \& Behavior, 12, 729-733. doi: 10.1089/cpb.2009.0003

Peluchette, J., \& Karl, K. (2010). Examining students' intended image on Facebook: "What were they thinking?!" Journal of Education for Business, 85, 30-37. Retrieved from http:// www.tandf.co.uk/journals/titles/08832323.asp

Pempek, T. A., Yermolayeva, Y. A., \& Calvert, S. L. (2009). College students' social networking experiences on Facebook. Journal of Applied Developmental Psychology, 30, 227-338. doi: 10.1016/j.appdev.2008.12.010

Putnam, L. L. (2004). Dialectical tensions and rhetorical tropes in negotiations. Organization Studies, 25, 35-53. doi: 10.1177/0170840604038179

Raacke, J. D., \& Bonds-Raacke, J. M. (2008). MySpace and Facebook: Applying the uses and gratifications theory to exploring friend-networking sites. CyberPsychology \& Behavior, 11, 169-174. doi: $10.1089 / \mathrm{cpb} .2007 .0056$ 
Rubin, H. J., \& Rubin, I. S. (2005). Qualitative interviewing: The art of hearing data (2nd ed.). Thousand Oaks, CA: Sage.

Schwartz, S. J., Côté, J. E., \& Arnett, J. J. (2005). Identity and agency in emerging adulthood: Two developmental routes in the individualization process. Youth \& Society, 37, 201-229. doi: 10.1177/0044118X05275965

Selwyn, N. (2009). Faceworking: Exploring students' education-related use of Facebook. Learning, Media and Technology, 34, 157-174. doi: 10.1080/17439880902923622

Smith, J. A. (1995). Semi-structured interviewing and qualitative analysis. In J. A. Smith, R. Harre \& L. Langenhove (Eds.), Rethinking methods in psychology (10th ed., pp. 9-26). Thousand Oaks, CA: Sage.

Stone, B. (2007, July 30). New scrutiny for Facebook over predators. New York Times. Retrieved from http://www.nytimes.com/2007/07/30/business/media/30facebook.html

Swartz, J. (2011, July 6). Facebook says membership has grown to 750 million. USA Today. Retrieved from http://www.usatoday.com/tech/news/2011-07-06-facebook-skype-growth_n.htm

Tracy, S. J. (2004). Dialectic, contradiction, or double bind? Analyzing and theorizing employee reactions to organizational tensions. Journal of Applied Communication Research, 32, 119-146. doi: 10.1080/0090988042000210025

Valenzuela, S., Park, N., \& Kee, K. F. (2009). Is there social capital in a social network site?: Facebook use and college students' life satisfaction, trust, and participation. Journal of Computer-Mediated Communication, 14, 875-901. doi: 10.1111/j.1083-6101.2009.01474.x 
Copyright of Western Journal of Communication is the property of Western States Communication Association and its content may not be copied or emailed to multiple sites or posted to a listserv without the copyright holder's express written permission. However, users may print, download, or email articles for individual use. 